\title{
ANALISIS VOLATILITAS DAN RISIKO HARGA KOMODITAS KEDELAI DI PASAR INTERNASIONAL
}

\section{VOLATILITY AND RISK ANALYSIS OF SOYBEAN COMMODITY PRICES IN INTERNATIONAL MARKET}

\author{
L. Cahya Rizqika ${ }^{1^{*}}$, I G.L. Parta Tanaya ${ }^{1}$, dan M. Yusuf ${ }^{1}$ \\ ${ }^{1}$ Program Studi Agribisnis Universitas Mataram, Mataram, Indonesia \\ *Email Penulis korespondensi: lalucahya@gmail.com
}

\begin{abstract}
ABSTRAK
Penelitian bertujuan untuk: (1) menganalisis volatilitas harga komoditas kedelai di pasar internasional pada tahun 1960-2021 ; (2) menganalisis risiko harga komoditas kedelai di pasar internasional pada tahun 1960-2021. Data yang digunakan adalah data kuantitatif berupa perkembangan harga kedelai di pasar internasional pada Januari 1960 - Maret 2021 yang diperoleh dari World Bank. Analisis data pada penelitian ini menggunakan ARCH GARCH dan CCV. Hasil penelitian menunjukkan bahwa : (1) volatilitas harga komoditas kedelai di pasar internasional dipengaruhi oleh volatilitas harga kedelai di pasar internasional pada satu periode sebelumnya dengan nilai ARCH sebesar 0,4193 dan varians harga kedelai di pasar internasional pada dua periode sebelumnya dengan nilai total GARCH sebesar 0,7116 ; (2) harga komoditas kedelai di pasar internasional pada periode Januari 1960 sampai dengan Maret 2021 menyimpang sebesar 2,06\% sampai dengan 47,89\% dari harga yang diharapkan.

Kata Kunci : Volatilitas Harga, Risiko Harga, Kedelai, Pasar Internasional
\end{abstract}

ABSTRACT
The aims of this study is to : (1) analyze the volatility of soybean commodity prices in the international market in 1960-2021; (2) analyzing the risk of soybean commodity prices in the international market in 1960-2021. The data used is quantitative data in the form of soybean price developments in the international market in January 1960 - March 2021 obtained from the World Bank. Data analysis in this study used ARCH GARCH and CCV. The results showed that : (1) the volatility of soybean commodity prices in the international market was influenced by the volatility of soybean prices in the international market in one previous period with an $\mathrm{ARCH}$ value of 0.4193 and a soybean price variance in the international market in the two previous periods with a total GARCH value of $0.7116 ;(2)$ soybean commodity prices in the international market in the period January 1960 to March 2021 deviated by $2.06 \%$ to $47.89 \%$ from the expected price.

Keywords : Price Volatility, Price Risk, Soybean, International Market

\section{PENDAHULUAN}

World Bank (2021) menjelaskan bahwa Indonesia memiliki jumlah penduduk terbesar keempat di dunia. Terkait dengan jumlah penduduk, Mahdi (2019) menjelaskan bahwa terdapat hubungan positif antara pertambahan jumlah penduduk dengan pertumbuhan kebutuhan pangan. Dari sekian ragam jenis pangan, terdapat beberapa di antaranya yang merupakan komoditas strategis pertanian. Komoditas strategis pertanian menurut Kementerian Pertanian RI (2020) merupakan komoditas-komoditas pertanian yang bernilai ekonomi cukup tinggi untuk menjaga ketahanan pangan (stabilitas harga) agar tidak terjadi inflasi.

Kementerian Pertanian RI (2020) mencatat bahwa salah satu komoditas strategis dengan produksi yang buruk adalah kedelai karena relatif kecilnya jumlah produksi yang diikuti oleh tren penurunan produksi (Tabel 1). Lebih lanjut lagi, Pusat Data Sistem Informasi Pertanian (2020) menjelaskan bahwa produksi kedelai dalam negeri cenderung stagnan sehingga tidak dapat mengimbangi permintaan kedelai. Hal ini menyebabkan tidak terpenuhinya kebutuhan domestik yang memberikan efek berantai kepada peningkatan volume impor yang ditujukan untuk mencukupi kebutuhan dan 
menekan harga kedelai dalam negeri. Hingga saat ini, pengembangan tanaman kedelai di Indonesia terkendala oleh persaingan penggunaan lahan dengan komoditas strategis lain dan semakin maraknya alih fungsi lahan di wilayah potensial. Meskipun demikian, peningkatan produksi kedelai baik dari kuantitas maupun kualitas terus diupayakan oleh pemerintah, melalui ekstensifikasi maupun intensifikasi.

Tabel 1. Produksi Komoditas Strategis Pertanian Periode 2015-2019

\begin{tabular}{lrrrrr}
\hline \multirow{2}{*}{ Nama Komoditas } & \multicolumn{5}{c}{ Produksi (Juta Ton) } \\
\cline { 2 - 6 } & \multicolumn{1}{c}{2015} & 2016 & 2017 & \multicolumn{1}{c}{2018} & 2019 \\
\hline Padi & 75,4 & 79,35 & 81,15 & 59,20 & 54,60 \\
Jagung & 19,61 & 23,58 & 28,92 & 21,66 & 22,59 \\
Kedelai & 0,96 & 0,86 & 0,53 & 0,65 & 0,42 \\
Cabai & 1,92 & 1,96 & 2,36 & 2,54 & 2,52 \\
Bawang Merah & 1,23 & 1,45 & 1,47 & 1,50 & 1,50 \\
Tebu & 2,50 & 2,20 & 2,12 & 2,17 & 2,23 \\
Daging Sapi / Kerbau & 0,54 & 0,55 & 0,51 & 0,52 & 0,51 \\
\hline
\end{tabular}

Sumber : Kementerian Pertanian RI (2020), diolah.

Pusat Data Sistem Informasi Pertanian (2020) menjelaskan bahwa ketidakseimbangan antara produksi dan konsumsi kedelai Indonesia melahirkan defisit kedelai yang berujung kepada buruknya impor kedelai berdasarkan import dependency ratio (IDR) dan self sufficiency ratio (SSR). Pada ada tahun 2015-2019, rata-rata IDR dan SSR kedelai Indonesia masing-masing sebesar 78,44\% dan $21,61 \%$ seperti pada Tabel 2.

Tabel 2. IDR dan SSR Kedelai Indonesia Tahun 2015-2019

\begin{tabular}{llllll}
\hline \multirow{2}{*}{ Uraian } & Tahun & & & \\
\cline { 2 - 6 } & 2015 & 2016 & 2017 & 2018 & 2019 \\
\hline Prod. (Ton) & 963.183 & 859.653 & 538.728 & 650.000 & 424.189 \\
Ekspor(Ton) & 1.188 & 1.345 & 1.473 & 2.055 & 3.682 \\
Impor (Ton) & 2.256 .932 & 2.261 .803 & 2.671 .914 & 2.585 .809 & 2.670 .086 \\
IDR (\%) & 70,11 & 72,49 & 83,26 & 79,96 & 86,39 \\
SSR (\%) & 29,91 & 27,54 & 16,78 & 20,09 & 13,71 \\
\hline
\end{tabular}

Sumber : Pusat Data dan Sistem Informasi Pertanian (2020), diolah.

Sholihah dan Kusnadi (2019) menggolongkan komoditas kedelai di pasar internasional sebagai komoditas dengan harga yang volatil. Hal tersebut sejalan dengan data dari World Bank (2021) terkait perkembangan harga komoditas kedelai di pasar internasional pada tahun 1960-2021. Hutabarat, Setiyanto, Riyai, dan Mayrowani (2015) menjelaskan bahwa volatilitas harga kedelai impor akan memengaruhi volatilitas harga produsen dan konsumen kedelai domestik. Hal tersebut mencerminkan adanya risiko harga yang dihadapi oleh konsumen dan produsen kedelai Indonesia. 


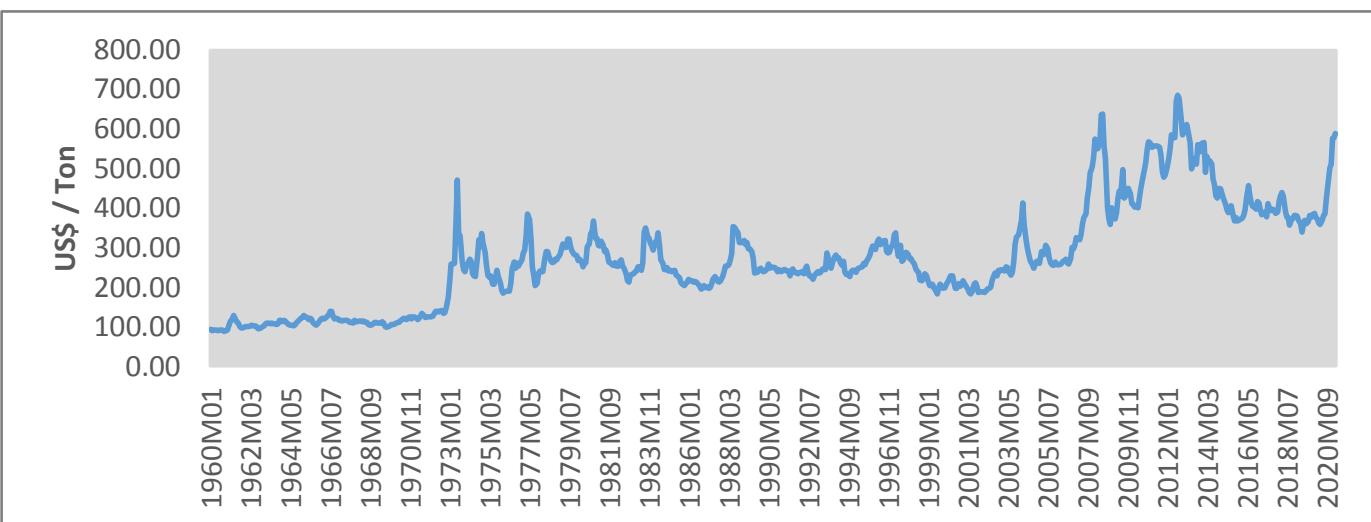

Gambar 1. Perkembangan Harga Kedelai Internasional 1960-2021

Sumber : World Bank (2021), diolah.

Badan Pengkajian dan Pengembangan Kebijakan Perdagangan (2015) menyatakan bahwa pemerintah berkepentingan menjamin hak atas pangan setiap warganya yang terhimpun dalam satuan masyarakat terkecil untuk mendapatkan pangan bagi keberlangsungan hidup. Jaminan tersebut meliputi stabilisasi harga dari volatilitas dan risiko harga. Oleh karenanya, pemerintah harus memiliki instrumen yang berdasarkan pemahaman terkait volatilitas dan risiko harga kedelai di pasar internasional untuk meredam dampak volatilitas dan risiko harga kedelai di pasar internasional.

Penelitian bertujuan untuk : (1) menganalisis volatilitas harga komoditas kedelai di pasar internasional pada periode tahun 1960-2021; (2) menganalisis risiko harga komoditas kedelai di pasar internasional pada periode tahun 1960-2021.

\section{METODE PENELITIAN}

Metode yang digunakan dalam penelitian ini adalah metode deret waktu dengan unit analisis berupa perkembangan harga kedelai di pasar internasional pada periode Januari tahun 1960 sampai dengan tahun Maret 2021. Jenis data yang digunakan adalah data kuantitatif. Sumber data berupa data sekunder time series harga komoditas kedelai di pasar internasional. Analisis data menggunakan ARCH-GARCH (Persamaan 1) untuk menganalisis volatilitas harga dan CCV (Persamaan 2) untuk menganalisis risiko harga.

$$
\begin{aligned}
& \sigma_{t}^{2}=\omega+\alpha_{1} \varepsilon_{t-1}^{2}+\alpha_{2} \varepsilon_{t-2}^{2}+\ldots .+\alpha_{p} \varepsilon_{t-p}^{2}+\lambda_{1} \sigma_{t-1}^{2}+\lambda_{1} \sigma_{t-2}^{2}+\ldots .+\lambda_{q} \sigma_{t-q}^{2} \\
& C C V_{t}=\frac{\sqrt{\omega+\alpha_{1} \varepsilon_{t-1}^{2}+\ldots .+\alpha_{p} \varepsilon_{t-p}^{2}+\lambda_{1} \sigma_{t-1}^{2}+\ldots .+\lambda_{q} \sigma_{t-q}^{2}}}{\left(\sum_{i=1}^{12} x_{i}\right) / 12} .100 \% \ldots \ldots . .
\end{aligned}
$$

Keterangan :

$\sigma 2 \mathrm{t}=$ volatilitas pada periode $\mathrm{t}$

$\mathrm{CCV}_{\mathrm{t}}=$ koefisien variasi bersyarat pada periode $\mathrm{t}$

$\omega=$ varibel konstan

$\varepsilon_{t-p}^{2} \quad=$ volatilitas harga pada $\mathrm{p}$ periode sebelum periode $\mathrm{t}$

$\sigma_{\mathrm{t}-\mathrm{q}}^{2}=$ varians pada $\mathrm{q}$ periode sebelum periode $\mathrm{t}$

$\alpha_{\mathrm{ps}} \quad=$ koefisien $\mathrm{ARCH}$ yang diestimasikan

$\lambda_{\mathrm{q}} \quad=$ koefisien GARCH yang diestimasikan

$\mathrm{x}_{\mathrm{i}} \quad=$ harga sebelum periode $\mathrm{t}$ 


\section{HASIL DAN PEMBAHASAN}

\section{Volatilitas Harga Komoditas Kedelai di Pasar Internasional}

ARCH GARCH dimulai dengan identifikasi efek ARCH yang berfungsi untuk mengidentifikasi gejala autokorelasi dan heteroskedastisitas. Identifikasi autokorelasi menunjukkan nilai ACF menjauhi nol dan probabilitas lag yang signifikan pada $a=5 \%$ pada Tabel 3. Dengan demikian, data mengandung gejala autokorelasi. Kemudian, identifikasi heteroskedastisitas menunjukkan nilai kurtosis yang lebih besar dari tiga sehingga data mengandung gejala heteroskedastisitas seperti yang ditunjukkan Tabel 4.

Tabel 3. Hasil Identifikasi Autokorelasi

\begin{tabular}{lrlll}
\hline Lag & Prob. & Signifikansi $(a=5 \%)$ & ACF & Autokorelasi \\
\hline $1-15$ & 0,000 & Signifikan & $>0,8$ & Ada \\
\hline
\end{tabular}

Tabel 4. Hasil Identifikasi Heteroskedastisitas

\begin{tabular}{lll}
\hline Referensi Kurtosis & Nilai Kurtosis & Heteroskedastisitas \\
\hline 3 & 3,328902 & Ada \\
\hline
\end{tabular}

Selanjutnya, dilakukan estimasi model ARIMA terbaik. Langkah pertama estimasi model ARIMA terbaik adalah uji stasioneritas seperti pada Tabel 5. Berdasarkan Uji ADF pada tingkat level, diperloleh nilai mutlak t statistik yang lebih kecil daripada nilai mutlak critical value $(4,372212<4,443649)$ pada taraf $a=5 \%$. Kemudian, nilai probabilitas Uji ADF pada tingkat level tidaklah signifikan pada $\mathrm{a}=$ $5 \%(0,0610>0,05)$. Dengan demikian, data belumlah stasioner sehingga perlu dilakukan differencing. Uji ADF pada differencing pertama memberikan hasil berupa nilai mutlak $t$ statistik yang lebih besar daripada nilai mutlak critical value $(22,61821>$ $4,443649)$ pada taraf $a=5 \%$ dan signifikansi pada $a=5 \%(0,0000<0,05)$. Dengan demikian, data stasioner pada differencing pertama.

Tabel 5. Hasil Identifikasi Stasioneritas

\begin{tabular}{lll|lll}
\hline Uji ADF (Level) & Uji ADF (1 $1^{\text {st }}$ Differencing) & \\
\hline t-Statistik & $\begin{array}{l}\text { Critical Value } \\
(\mathrm{a}=5 \%)\end{array}$ & Probabilitas & t-Statistik & $\begin{array}{l}\text { Critical Value } \\
(\mathrm{a}=5 \%)\end{array}$ & Probabilitas \\
\hline$-4,372212$ & $-4,443649$ & 0,0610 & $-22,61821$ & $-4,443649$ & 0,0000 \\
\hline
\end{tabular}

Langkah selanjutnya adalah mencari model ARIMA terbaik. Pada Gambar 2, plot ACF dan plot PACF mengalami cut off setelah lag pertama. Hal tersebut bermakna bahwa model ARIMA terbaik adalah ARIMA $(1,1,0)$ atau ARIMA $(0,1,1)$. Selanjutnya, untuk menentukan model yang terbaik, digunakan kriteria : (1) koefisien yang signifikan, (2) nilai akaike info criterion (AIC) terkecil, (3) nilai schwarz criterion (SC) terkecil, (4) nilai standard error of regression (SEoR) terkceil, (5) nilai sum square residual $\left(S^{2} \mathrm{R}\right)$ terkecil, (6) nilai adj $\mathrm{R}$ square terbesar, dan (7) nilai F statistik terbesar. Hasil pencarian menunjukkan bahwa ARIMA $(1,1,0)$ merupakan model yang terbaik (Tabel 6). 


\begin{tabular}{|c|c|c|c|c|c|c|}
\hline Autocorrelation & Partial Correlation & & $A C$ & PAC & Q-Stat & Prob \\
\hline 口 & ! & 1 & 0.177 & 0.177 & 23.032 & 0.000 \\
\hline 1 & $\phi_{1}$ & 2 & 0.058 & 0.027 & 25.503 & 0.000 \\
\hline 14 & d. & 3 & -0.034 & -0.050 & 26.355 & 0.000 \\
\hline , & 叫 & 4 & -0.039 & -0.027 & 27.470 & 0.000 \\
\hline d. & 1. & 5 & -0.057 & -0.043 & 29.886 & 0.000 \\
\hline 14 & 11 & 6 & -0.025 & -0.007 & 30.347 & 0.000 \\
\hline 11 & 11 & 7 & 0.011 & 0.019 & 30.433 & 0.000 \\
\hline
\end{tabular}

Gambar 2. Plot ACF dan PACF (1st Difference)

Tabel 6. Hasil Pencarian Model ARIMA Terbaik

Model Kriteria (tanda * menunjukkan pemenuhan kriteria model terbaik)

\begin{tabular}{llllllll} 
ARIMA & Sig. $(a=5 \%)$ & AIC & SC & SEoR & $S^{2} \mathrm{R}$ & Adj R $^{2}$ & F Statistik \\
\hline $1,1,0$ & $0,0000^{*}$ & $8,7045^{*}$ & $8,7233^{*}$ & $18,7512 *$ & $257.027^{*}$ & $0,0286^{*}$ & $11,7951^{*}$ \\
$0,1,1$ & $0,0000^{*}$ & 8,7073 & 8,7261 & 18,7778 & 257.756 & 0,0258 & 10,7267
\end{tabular}

Tahapan selanjutnya adalah mencari model ARCH GARCH terbaik. Model ARCH GARCH terbaik memiliki : (1) koefisien yang signifikan, (2) nilai akaike info criterion (AIC) terkecil, (3) nilai schwarz criterion (SC) terkecil, (4) nilai standard error of regression (SEoR) terkceil, (5) nilai sum square residual $\left(S^{2} R\right)$ terkecil, (6) nilai adj $R$ square terbesar, dan (7) nilai log likelihood terbesar. Hasil pencarian menunjukkan bahwa ARCH-GARCH $(1,2)$ adalah model yang terbaik seperti pada Tabel 7.

Tabel 7. Hasil Pencarian Model ARCH GARCH Terbaik

\begin{tabular}{llllllll}
\hline ARCH & \multicolumn{6}{l}{ Kriteria (Tanda * menunjukkan pemenuhan kriteria model terbaik) } \\
\cline { 2 - 3 } & $\begin{array}{l}\text { Sig. } \\
\text { Ga }\end{array}$ & AIC & SC & SEoR & S $^{2} \mathrm{R}$ & Adj. R & $\begin{array}{l}\text { Log } \\
\text { likelihood }\end{array}$ \\
\hline 1,0 & Sig. $^{*}$ & 8,4538 & 8,4789 & 18,7821 & 257.875 & 0,0266 & $-3.094,35$ \\
1,1 & Sig. $^{*}$ & $7,9889 *$ & $8,0203 *$ & 18,7858 & 257.976 & 0,0263 & $-2.922,96$ \\
1,2 & Sig. $^{*}$ & 7,9898 & 8,0275 & $18,7708 *$ & $257.562 *$ & $0,0278 *$ & $-2.922,28 *$ \\
\hline
\end{tabular}

Langkah berikutnya adalah evaluasi model. Model dinyatakan memadai apabila memenuhi kriteria : (1) terdistribusi secara normal, (2) tidak mengandung gejala autokorelasi, dan (3) tidak mengandung gejala heteroskedastisitas. Berdasarkan hasil Uji Jarque Berra (Tabel 8), nilai $p$ value yang dihasilkan lebih kecil daripada tingkat a (5\%). Dengan demikian, data memenuhi kriteria terdistribusi secara normal. Kemudian, nilai ACF menunjukkan nilai yang mendekati nol dan probabilitas lag 1 sampai 15 tidak signifikan pada $a=5 \%$ yang ditunjukkan pada Tabel 9. Dengan demikian, model tidak mengandung gejala autokorelasi. Terakhir, berdasarkan hasil Uji ARCH LM, diperoleh nilai probabilitas yang tidak signifikan pada $a=5 \%$ (Tabel 10). Dengan demikian, model tidak mengandung gejala heteroskedastisitas.

Tabel 8. Hasil Evaluasi Normalitas Model

\begin{tabular}{|c|c|c|c|c|}
\hline \multicolumn{2}{|c|}{ Nilai Jarque Berra } & $p$ value & Keteran & \\
\hline \multicolumn{2}{|c|}{$1.537,950$} & 0,00000 & erdistribusi Nol & al $(a=5 \%)$ \\
\hline \multicolumn{5}{|c|}{ Tabel 9. Hasil Evaluasi Gejala Autokorelasi Model } \\
\hline Lag & Prob. & Signifikansi $(a=5 \%)$ & $\mathrm{ACF}$ & Autokorelasi \\
\hline $1-15$ & $>0,9$ & Tidak Signifikan & Mendekati 0 & Tidak Ada \\
\hline \multicolumn{5}{|c|}{ Tabel 10. Hasil Evaluasi Heteroskedastisitas Model } \\
\hline \multicolumn{2}{|c|}{ Prob. F-statistic } & Prob. Chi-Square & \multicolumn{2}{|c|}{ Keterangan } \\
\hline \multicolumn{2}{|c|}{0,9374} & 0,9373 & \multicolumn{2}{|c|}{ Homoskedastisitas $(a=5 \%)$} \\
\hline
\end{tabular}


Berdasarkan model ARCH GARCH $(1,2)$, diperoleh model :

$$
\sigma_{t}^{2}=1.5897+0,4193 \varepsilon_{t-1}^{2}+0,4794 \sigma_{t-1}^{2}+0,2322 \sigma_{t-2}^{2}
$$

Persamaan 3 menunjukkan bahwa volatilitas harga komoditas kedelai di pasar internasional dipengaruhi oleh volatilitas harga kedelai di pasar internasional pada satu periode sebelumnya dan varians di pasar internasional pada dua periode sebelumnya. Nilai koefisien ordo suku ARCH sebesar 0,4193 menunjukkan bahwa variabilitas harga kedelai di pasar internasional dari satu waktu ke waktu lainnya relatif tidak bervariasi dalam jangka pendek. Adapun nilai total dari ordo suku GARCH sebesar 0,7116 bermakna bahwa volatilitas harga komoditas kedelai memiliki persistensi yang cenderung akan terjadi dalam waktu yang relatif lama.

Volatilitas merupakan varian bersyarat. Hal tersebut bermakna bahwa nilai volatilitas tidak dapat dipahami dengan satuan harga. Oleh karenanya, Persamaan 3 ditransformasikan menjadi rangkaian standar deviasi bersyarat, yaitu :

$$
\sigma_{t}=\sqrt{1.5897+0,4193 \varepsilon_{t-1}^{2}+0,4794 \sigma_{t-1}^{2}+0,2322 \sigma_{t-2}^{2}}
$$

standar deviasi bersyarat selanjutnya menghasilkan rangkaian standar deviasi bersyarat harga kedelai internasional pada periode Januari 1960 sampai dengan Maret 2021 (Gambar 4).

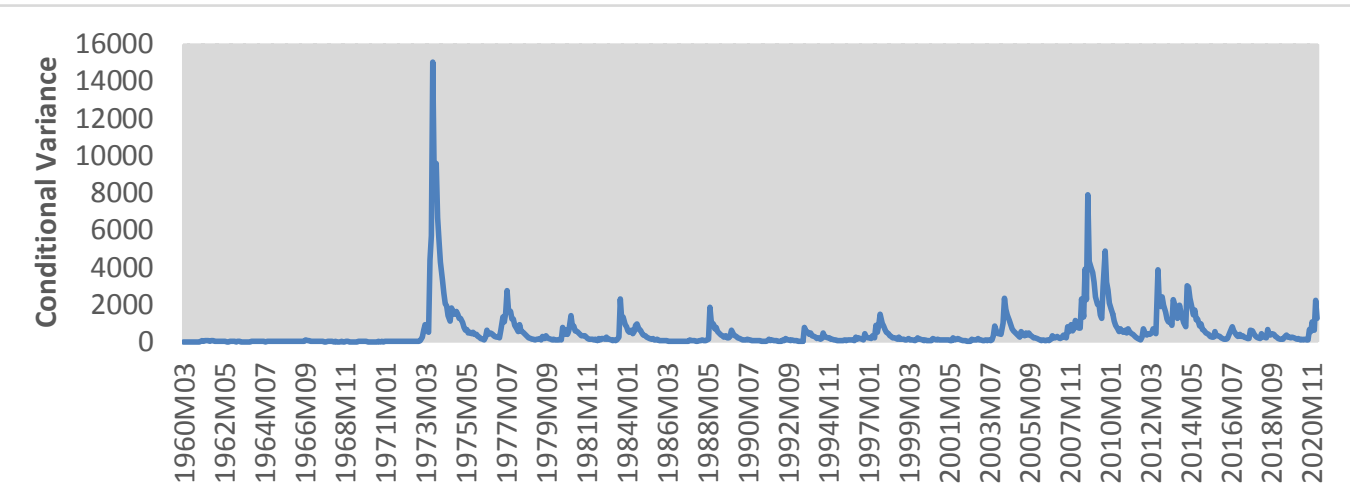

Gambar 3. Volatilitas Harga Kedelai di Pasar Internasional

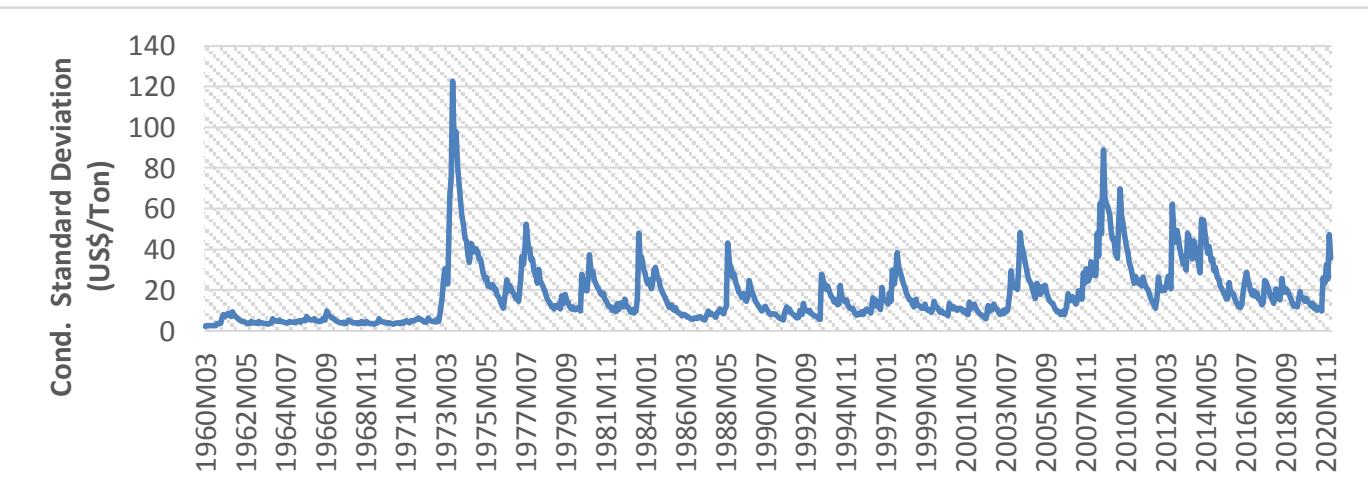

Gambar 4. Standar Deviasi Bersyarat Harga Kedelai di Pasar Internasional

Volatilitas harga komoditas kedelai di pasar internasional dapat diklasifikasikan menjadi tiga periode, yaitu (1) tahun 1960-1972, (2) tahun 1973-2006, dan (3) tahun 2007 hingga saat ini. Pembagian periode tersebut didasarkan kepada karakteristik volatilitas harga yang telah terjadi (Gambar 3), yaitu terjadi titik balik perubahan pola volatilitas pada tahun 1973 dan 2007. Periode tahun 1960-1972 merupakan masa di mana lonjakan harga relatif stabil di bawah level US\$15/Ton. Kemudian, periode berikutnya ditandai dengan terjadinya krisis pangan tahun 1973-1974. Pada krisis 
pangan tahun 1973-1974, lonjakan harga mencapai level tertinggi sepanjang sejarah, yaitu US\$122,64/Ton. Setelah tahun 1974, lonjakan harga menjadi lebih tinggi dari masa sebelumnya (sebelum 1973). Oleh karenanya, krisis pangan 1973-1974 dapat disebut sebagai titik balik pertama volatilitas harga komoditas kedelai di pasar internasional. Selanjutnya, lonjakan harga komoditas kedelai pada rentang tahun 1975 sampai dengan akhir 2006 bergerak di bawah level US\$60/Ton. Pasca tahun 2006, volatilitas memasuki babak baru yang kembali ditandai dengan krisis pangan, yaitu krisis pangan tahun 2007-2008. Lonjakan harga pada tahun 2007-2008 tergolong salah satu yang paling ekstrem, yaitu mencapai level US\$88,99/Ton. Setelah tahun 2008, volatilitas memasuki babak yang baru dengan pola yang tidak serupa dengan tahuntahun sebelumnya.

\section{Risiko Harga Komoditas Kedelai di Pasar Internasional}

Risiko harga komoditas kedelai di pasar internasional pada penelitian ini dianalisis menggunakan koefisien variasi bersyarat. Pertama, Persamaan 4 ditransformasikan ke dalam model koefisien variasi menjadi model koefisien variasi bersyarat, yaitu :

$$
C C V_{t}=\frac{\sqrt{1.5897+0,4193 \varepsilon_{t-1}^{2}+0,4794 \sigma_{t-1}^{2}+0,2322 \sigma_{t-2}^{2}}}{\left(\sum_{t=1}^{12} x_{i}\right) / 12} 100 \%
$$

Kemudian, berdasarkan persamaan 5 diperoleh rangkaian tingkat risiko harga komoditas kedelai di pasar internasional pada periode Januari 1960 sampai dengan Maret 2021 dengan rentang 2,06\% sampai dengan 47,89\% (Gambar 5).

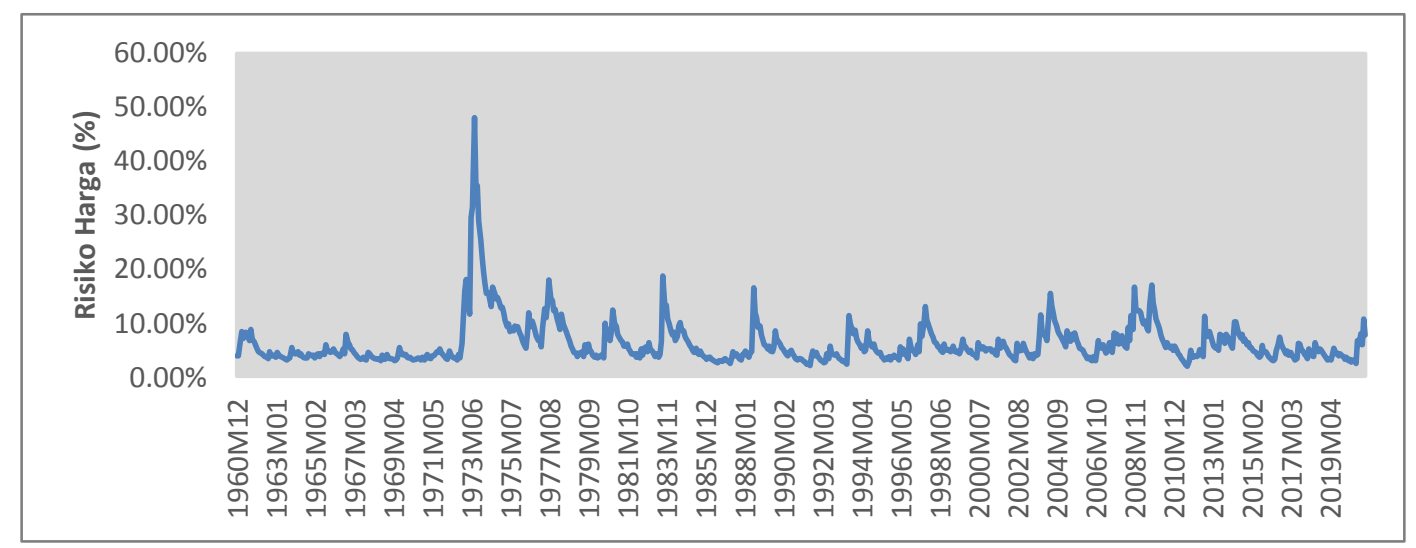

Gambar 5. Risiko Harga Kedelai di Pasar Internasional

Pengaruh nyata dari risiko harga dapat dipahami dengan mentransformasikan Persamaan 5 menjadi model surplus importir (Persamaan 6) dan surplus eksportir (Persamaan 7). Selanjutnya, model surplus importir dan surplus eksportir disajikan dalam bentuk rangkaian estimasi nilai surplus importi-eksportir sebagaimana yang disajikan pada Gambar 6 dan rangkaian estimasi rentang surplus harga sebagaimana yang disajikan pada Gambar 7.

$$
\begin{aligned}
& I S_{t}=W P_{t}-\sqrt{1.5897+0,4193 \varepsilon_{t-1}^{2}+0,4794 \sigma_{t-1}^{2}+0,2322 \sigma_{t-2}^{2}} . \\
& E S_{t}=W A_{t}+\sqrt{1.5897+0,4193 \varepsilon_{t-1}^{2}+0,4794 \sigma_{t-1}^{2}+0,2322 \sigma_{t-2}^{2}}
\end{aligned}
$$

Keterangan :

IS $_{\mathrm{t}}=$ Surplus importir pada periode $\mathrm{t}$

$\mathrm{WP}_{\mathrm{t}}=$ Willingness to pay pada periode $\mathrm{t}$

$\mathrm{ES}_{\mathrm{t}}=$ Surplus eksportir pada periode $\mathrm{t}$ 
$\mathrm{WA}_{\mathrm{t}}=$ Willingness to accept pada periode $\mathrm{t}$

$\varepsilon_{\mathrm{t}-1}^{2}=$ volatilitas harga pada satu periode sebelum periode $\mathrm{t}$

$\sigma_{\mathrm{t}-1}^{2}=$ varians pada satu periode sebelum periode $\mathrm{t}$

$\sigma_{\mathrm{t}-2}^{2}=$ varians pada dua periode sebelum periode $\mathrm{t}$

Kerugian finansial untuk importir terjadi ketika harga komoditas menjadi lebih tinggi daripada harga beli yang diharapkan dan berlaku sebaliknya untuk eksportir. Apabila importir mengalami kerugian finansial, maka eksportir akan mengalami surplus eksportir, yaitu perbedaan positif antara tingkat penerimaan yang diperoleh oleh eksportir terhadap tingkat penerimaan minimal yang masih bersedia diterima oleh eksportir. Sebaliknya, apabila eksportir mengalami kerugian finansial, maka importir mengalami surplus importir, yaitu perbedaan negatif antara tingkat pengeluaran yang dikeluarkan oleh importir terhadap tingkat pengeluaran maksimum yang masih bersedia dibayarkan oleh importir.

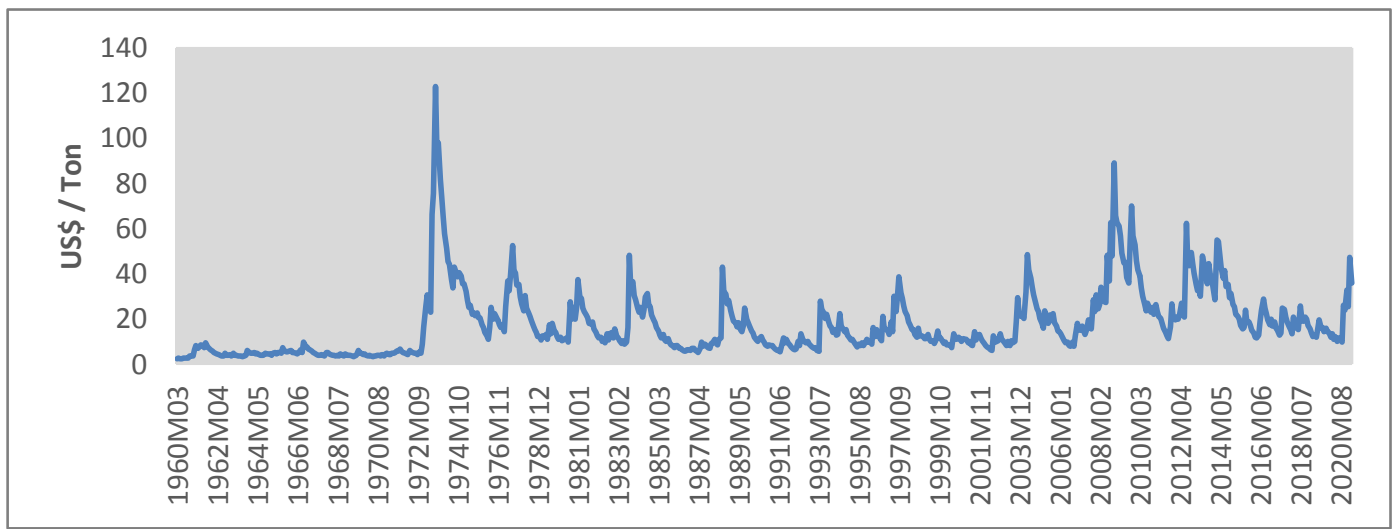

Gambar 6. Nilai Surplus Eksportir / Importir Kedelai Internasional

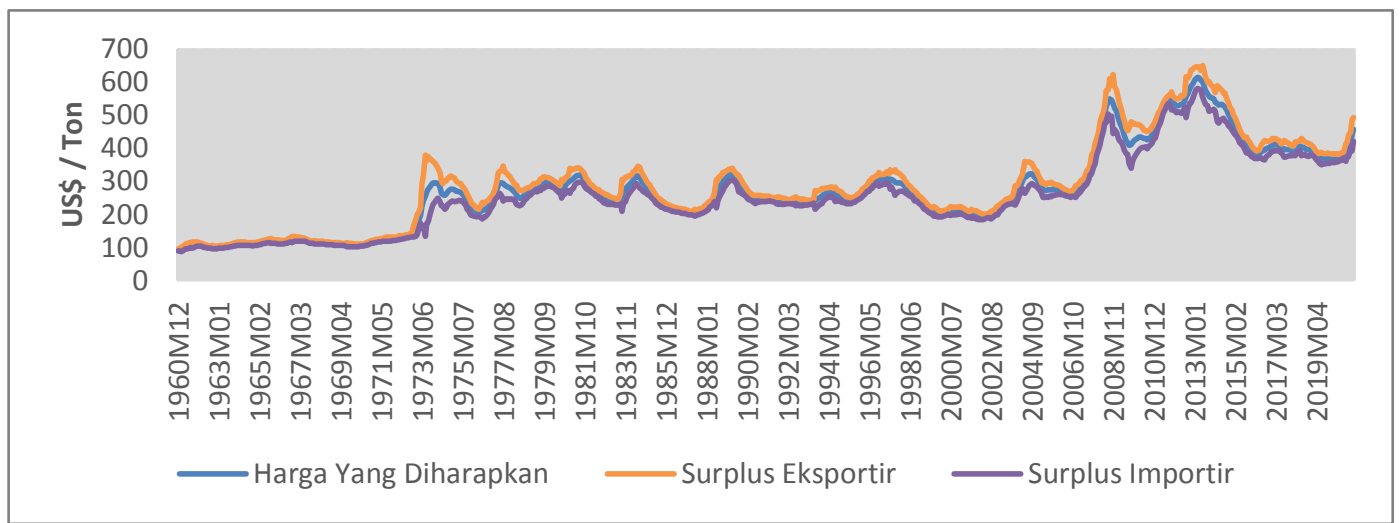

Gambar 7. Rentang Surplus Harga Komoditas Kedelai Internasional

Surplus eksportir dan surplus importir komoditas kedelai di pasar internasional silih berganti sepanjang tahun 1960-2021 dengan probabilitas kejadian surplus eksportir dan importir pada bulan tertentu relatif seimbang satu sama lain, yaitu hanya berkisar antara 40\%-60\% (Gambar 8). Tiga waktu dengan probabilitas terbaik untuk terjadinya surplus eksportir berada pada bulan Maret, Mei, dan Juni dengan masingmasing probabilitas kejadian sebesar 54,1\%, 56,67\%, dan 55\%. Adapun tiga waktu dengan probabilitas terbaik untuk terjadinya surplus importir berada pada bulan September, Oktober, dan November dengan masing-masing probabilitas kejadian sebesar 55\%, 58,33\%, dan 60\%. Mengingat bahwa probabilitas kejadian surplus eksportir dan importir memiliki selisih yang kecil -mendekati 50\% : 50\%-, 
probabilitas kejadian surplus eksportir dan importir tidak dapat digunakan sebagai satusatunya pertimbangan dalam menentukan keputusan waktu ekspor dan impor.

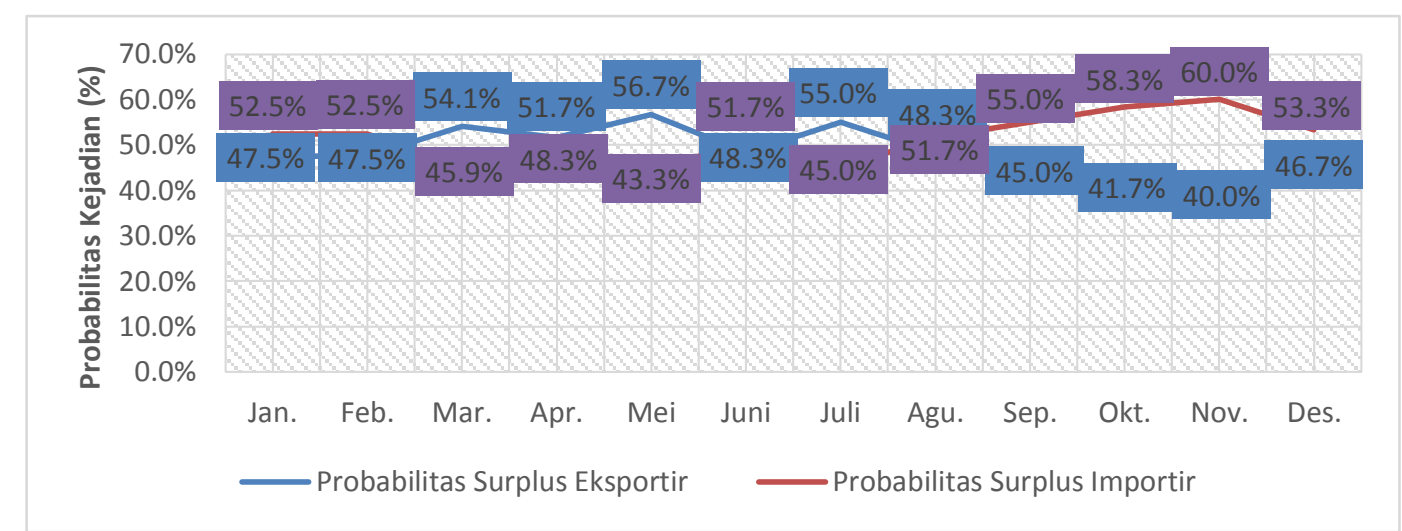

Gambar 8. Probabilitas Kejadian Surplus Importir dan Eksportir

Keputusan waktu untuk melaksanakan ekspor dan impor sebaiknya dilakukan dengan mempertimbangkan perilaku price maker kedelai di pasar internasional. Pusat Data dan Sistem Informasi Pertanian (2020) menjelaskan bahwa Amerika Serikat dan Brazil merupakan eksportir utama dan China merupakan importir utama komoditas kedelai di pasar internasional. Amerika Serikat dan Brazil merupakan dua negara dengan ekspor kedelai terbesar di dunia. Pada tahun 2014-2018, Amerika Serikat memiliki rata-rata ekspor kedelai sebesar 51,48 juta ton per tahun atau berkontribusi sebesar 37,28\% terhadap total ekspor kedelai dunia, sedangkan Brazil memiliki ratarata ekspor kedelai mencapai 60,67 juta ton per tahun atau berkontribusi sebesar 43,94\% terhadap total ekspor kedelai dunia. Hal tersebut berarti bahwa Amerika Serikat dan Brazil telah mewakili pangsa ekspor kedelai sebesar $81,22 \%$ terhadap total ekspor kedelai dunia. Dari sisi impor, China melakukan rata-rata impor kedelai sebesar 84,12 juta ton per tahun atau berkontribusi sebesar $60,68 \%$ terhadap total impor kedelai dunia pada tahun 2014-2018. Dengan demikian, harga kedelai di pasar internasional sangat berpotensi untuk ditentukan oleh perilaku ekspor dari Amerika Serikat dan Brazil serta perilaku impor dari China.

Indonesia merupakan price taker komoditas kedelai dari pasar internasional. Hal tersebut sebagaimana penjelasan Pusat Data dan Sistem Informasi Pertanian (2020) bahwa pada tahun 2014-2018 : (1) rata-rata ekspor kedelai Indonesia sebesar 9 ton / tahun atau berkontribusi sebesar $0,007 \%$ terhadap ekspor kedelai dunia ; (2) rata-rata impor kedelai Indonesia sebesar 2,32 juta ton / tahun atau berkontribusi sebesar 1,67\% terhadap total impor kedelai dunia. Menimbang penawaran dan permintaan kedelai Indonesia yang rendah terhadap total penawaran dan permintaan dunia, Indonesia sebaiknya memperhatikan pola perdagangan price maker untuk memperoleh harga beli yang terbaik - memperhatikan irisan waktu di mana penawaran kedelai dari Amerika Serikat dan Brazil meningkat, sementara permintaan kedelai dari China menurun.

\section{KESIMPULAN DAN SARAN}

Berdasarkan hasil dan pembahasan, diperoleh kesimpulan sebagai berikut : (1) volatilitas harga komoditas kedelai di pasar internasional pada periode Januari tahun 1960 sampai dengan Maret tahun 2021 dipengaruhi oleh volatilitas harga kedelai di pasar internasional pada satu periode sebelumnya dengan nilai ordo suku ARCH sebesar 0,4193 dan varians harga kedelai di pasar internasional pada dua periode sebelumnya dengan nilai total dari ordo suku GARCH sebesar 0,7116 ; (2) harga komoditas kedelai 
di pasar internasional pada periode Januari tahun 1960 sampai dengan Maret tahun 2021 menyimpang sebesar 2,06\% sampai dengan 47,89\% dari harga yang diharapkan.

Penelitian selanjutnya yang terkait dengan volatilitas dan risiko harga kedelai di pasar internasional sebaiknya mengkaji pengaruh antar variabel yang memiliki keterkaitan erat dengan volatilitas dan risiko harga kedelai di pasar internasional, seperti pengaruh pola perdagangan price maker komoditas kedelai di pasar internasional terhadap volatilitas dan risiko harga kedelai di pasar internasional; (2) importir kedelai sebaiknya proaktif dalam memperhatikan pola perdagangan price maker komoditas kedelai di pasar internasional sehingga dapat menyusun strategi impor yang tepat ; (3) penyusun kebijakan di Indonesia sebaiknya memperhatikan tingkat volatilitas dan risiko harga komoditas kedelai di pasar internasional beserta hal-hal yang memengaruhinya dalam merumuskan kebijakan yang terkait dengan ekspor-impor dan harga domestik.

\section{DAFTAR PUSTAKA}

Badan Pengkajian dan Pengembangan Kebijakan Perdagangan. (2015). Laporan Akhir Kajian Efektivitas Kebijakan Impor Produk Pangan Dalam Rangka Stabilisasi Harga. Badan Pengkajian dan Pengembangan Kebijakan Perdagangan Kementrian Perdagangan RI: Jakarta.

Hutabarat B. F., Setiyanto A., Rivai R. S., \& Mayrowani H. (2015). Kajian Kebijakan Stabilisasi Harga Beras / Gabah, Jagung, dan Kedelai. Laporan Akhir Analisis Kebijakan TA 2014. Pusat Sosial Ekonomi dan Kebijakan Pertanian Badan Penelitian dan Pengembangan Pertanian Departemen Pertanian: Bogor.

Kementerian Pertanian RI. (2020). Rencana Strategis Kementerian Pertanian 20202024. Kementerian Pertanian Republik Indonesia: Jakarta.

Mahdi, N. N. (2019). Analisis Faktor-Faktor Yang Memengaruhi Impor Kedelai di Indonesia. Skripsi. Departemen Agribisnis Fakultas Ekonomi dan Manajemen, Institut Pertanian Bogor. Bogor.

Pusat Data dan Sistem Informasi Pertanian. (2020). Outlook Kedelai. Pusat Data dan Sistem Informasi Pertanian Kementerian Pertanian: Jakarta.

Sholihah, F. dan Kusnadi N. 2019. Dampak Pengembangan Bio Fuels Terhadap Volatilitas Harga Beberapa Komoditas Pangan di Pasar Dunia. Jurnal Agro Ekonomi 37 (2) : 157-170.

World Bank. (2021). Population 2020. World Development Indicators Database, World Bank, Ed. 1 July 2021.

World Bank. (2021). World Bank Commodity Price Data (The Pink Sheet). https://thedocs.worldbank.org/en/doc/5d903e848db1d1b83e0ec8f744e555700350012021/related/CMO-Historical-Data-Monthly.xlsx, diakses pada 15 November 2021. 